\begin{tabular}{|c|c|c|}
\hline $\begin{array}{c}\text { ReSEARCH } \\
\text { ARTICLE }\end{array}$ & $\begin{array}{r}\text { ADVANCE RESEARC } \\
\text { Volume } 7 \mid \text { Issue } 2 \mid \text { De }\end{array}$ & $\begin{array}{l}\text { F SOCIAL SCIENCE } \\
\text { e ISSN-2231-6418 }\end{array}$ \\
\hline $0=$ & DOI: 10.15740/HAS/ARJSS/7.2/192-198 & Visit us : www.researchjournal.co.in \\
\hline
\end{tabular}

\title{
Effect of personal and familial causes towards suicidal tendencies among the youth
}

Lidya Ch. Momin* and Gaytri Tiwari

Department of Human Development, College of Home Science, Maharana Pratap University of Agriculture and Technology, UDAIPUR (RAJASTHAN) INDIA

(Email: lidyamomin@yahoo.com)

\section{ARTICLE INFO :}

$\begin{array}{lll}\text { Received } & : & 08.07 .2016 \\ \text { Revised } & : & 13.10 .2016 \\ \text { Accepted } & : & 25.10 .2016\end{array}$

KEY WORDS :

Personal and familial causes, Suicidal tendencies and youth

HOW TO CITE THIS ARTICLE :

Momin, Lidya Ch. and Tiwari, Gaytri (2016). Effect of personal and familial causes towards suicidal tendencies among the youth. Adv. Res. J. Soc. Sci., 7 (2) : 192-198, DOI: 10.15740/HAS/ARJSS/ 7.2/192-198.

*Author for correspondence

\begin{abstract}
The present study was undertaken with specific objective to study the effect of personal and familial causes towards suicidal tendencies among the youth. A total sample of 400 youth (200 boys and 200 girls) was selected purposively from the Udaipur city and the age range was between 19-22 years of the youth. It was found that the girls had very high suicidal tendencies due to personal causes and boys had average. Further in the case of both girls and boys had high level of suicidal tendencies due to familial causes. The finding indicates that differences were significant in relation to personal and familial causes towards suicidal tendencies among the youth.
\end{abstract}

